INTERDISCIPLINARIA ARCHAEOLOGICA

\title{
Probable Sources and Refining Technology of Parthian and Sasanian Silver Coins
}

\author{
Farhang Khademi Nadooshan ${ }^{\mathrm{a}^{*}}$, Mostafa Khazaie \\ ${ }^{a}$ Department of Archaeology, Tarbiat Modares University, Tehran, Iran
}

\section{ARTICLE INFO}

\section{Article history:}

Received: 14 June 2011

Accepted: 1 December 2011

\section{Key words:}

Parthian

Sasanian

technology

silver

lead

coins

\begin{abstract}
$A B S T R A C T$
Parthians and Sasanians refined silver to mint coins, and to make luxury utensils and decorations popular within royal and wealthy families. Most silver used in Persia was extracted from galena and cerrusite mines. These ores were refined for silver during which other metals such as lead were extracted. Some of these matrix elements remained in the refined silver. In this article we compare the concentrations of lead in select coins in order to better understand the technology of extraction and to identify the sources of the silver used during both dynasties.
\end{abstract}

\section{Introduction}

The chemical composition of ancient coins is useful for understanding the political and economic conditions of the period of study. The chemical elements present in coins may identify the sources of the metal, and the level of technology used to extract metal for minting.

\subsection{Sources of silver}

Silver was used by officials, jewelers and in coins. This metal played a major role as a monetary instrument in classical Iran. Due to the lack of silver mines in Iran, silver was a byproduct of lead and zinc ores extracted from cerussite mines in the Parthian and Sasanian periods.

The first commercially available silver artifacts can be seen in Tape Sialk and other archeological sites in Iran (Nezafati et al. 2008, 337-338). In a broad geological survey Momenzadeh (2006) located more than 34 lead-zinc mines from prehistory to the Islamic period. Momenzadeh made note of several additional historic mines that were destroyed and have not been located. Other mineralogical work conducted in Anatolia by Jesus (1978, 97-102) criticized Yakar (1976, 118-28) whose research was limited to surface finding with

${ }^{*}$ Corresponding author. E-mail: khademif@modares.ac.ir little on the sources of silver in Beraz and Balya, and did not include any metallurgical study. In a later surface survey Yener reported on several silver mines from the Neolithic to the Ottoman period $(1986,169-472)$ in Anatolia. In other exemplary research Yener (1983, 1-15) examined prehistoric exchange models and conducted chemical and lead isotope analysis (these are more reliable than other isotopes due to their proximity in time to the sites in Iran). These scholars focused on identifying sources of ores and were not seeking to identify relationships to silver production nor to connect artifacts to source mines.

It is thought that lead concentrations in silver coins reflect the quality of refining technology: the less lead, the better process of extracting silver from lead and zinc ores. It is possible that silver in all the ancient mines was extracted by reducing the amount of lead in the silver by cupellation. The average concentration of the remaining lead was between 0.5 to $1 \%$. In the Parthian and Sasanian periods lead mines produced silver largely from oxidizing ores such as cerussite and argentiferous galena $(\mathrm{PbS})$ (Meyer 2003, 271-288). Specific ores or specific geological deposits also have different ratios of traces of rare earth elements, that correspond to the ratios found in refined silver.

In our study of possible sources of silver in Iran we investigated the occurrence of gold present (Meyer 1972, 


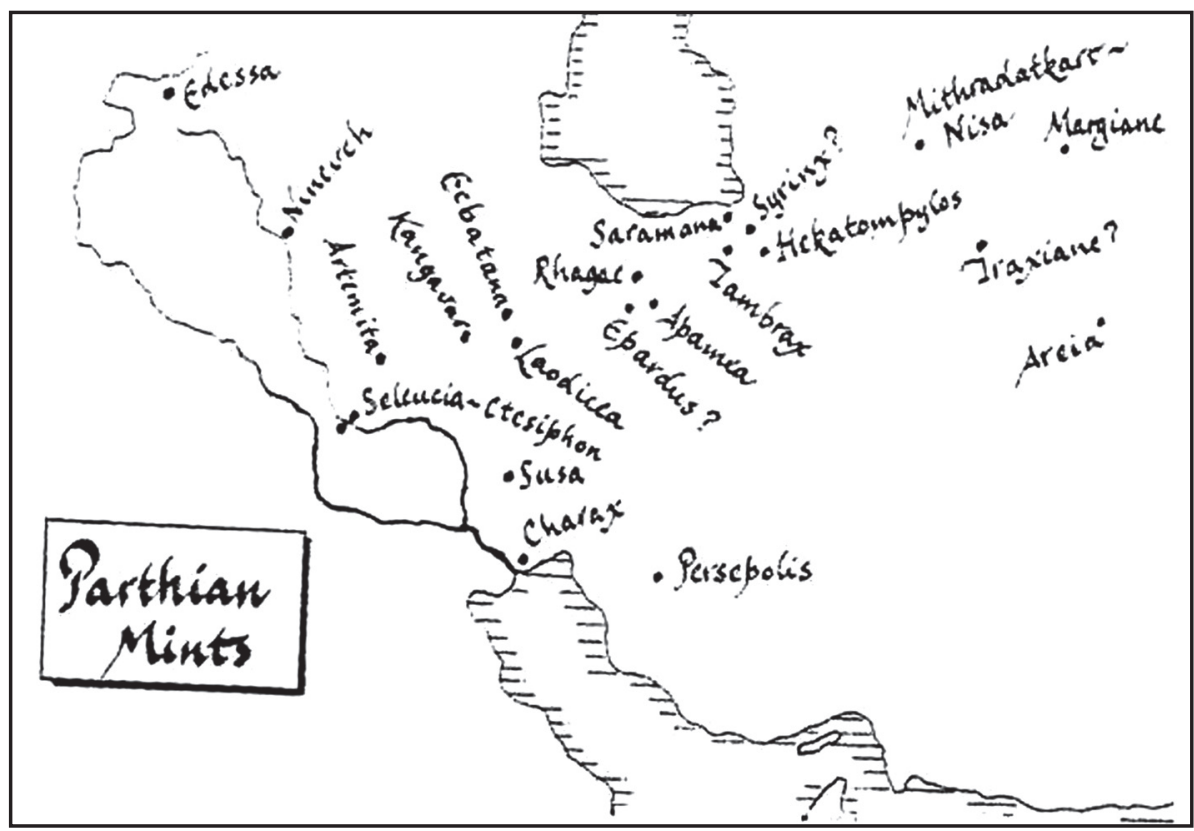

Figure 1. Parthian mint houses.

183-193) in silver ores and silver coins during the thousand year period of the Parthian and Sasanian dynasties.

\subsection{Analytical technique}

Many non-destructive spectroscopic methods are used on silver objects including PIXE (Smith 2005) and XRF. Both XRF and PIXE were deemed suitable for use in this research, and in both lead was selected as the traces element. These instruments have advantages and disadvantages that have been thoroughly discussed in the literature.

Several scholars including Hall (Hall et al. 1963, 53-78) have demonstrated the application of XRF with ceramics. Condamin (Condamin, Picon 1964, 98-105) used it to study corrosion on silver coins which would otherwise have altered spectroscopy findings. XRF can help us study the provenance of an object (Banks, Hall 1963, 31-36), its paint (Cesareo et al. 1972, 65-78) and enamel. Of course, newer instruments like the Neutron Activation Analysis (NAA) have been applied to similar ends, but XRF and PIXE are the most commonly used non-destructive approaches. XRF and PIXE can help determination, chemical composition, methods of manufacture and the provenance of archaeological metals (Guerra 1998, 78).

After working on more than two hundred coins with NAA, Gordus identified the relationship between fineness of Sasanian silver issues and numismatic classifications (Gordus 1995, 613-619). Several studies have been done on Sasanian silver coins and their contemporary issues (Hajivaliei et al. 1999, 645-650; Vijayan et al. 2004, 353-356; Rautray et al. 2011, 1385-1389), but these have only reported on the chemical composition of the coins and not their sources or refining technology.

\subsection{Historical Background}

After the invasion of Persia by Alexander the Great (356-323 $\mathrm{BC}$ ) the Seleucid dynasty ruled for nearly three centuries. The
Parthians forced the Seleucids out of Persia and later from Iran. The fabled leader Arasces (247-211 BC) developed his power base in Parthia, from which the Parthians expanded during the reign of Mithridates I (171-138 BC), extending their power to the east and recapturing several Seleucid satrapies under the power of the Seleucid king. After Mithridates I Parthian expansion abated for a time.

After the long war with the Seleucids the Parthians came into contact with the Roman Empire and a long struggle ensued over the occupation of Mesopotamia and Armenia. Parthian rule was effectively ended by another Iranian dynasty under Ardashir I (224-241 AD), and known as the Sasanian kingdom. Ardashir I occupied Parthia, ending the rule of Artabanus V, and re-organized the occupied kingdom. Shapur I (241-272 AD) went on to establish a political settlement that continued until the long war with Roman weakened both dynasties. Sasanian rule was ended by a Muslim army and small kingdoms established throughout Iran.

\subsection{Parthian and Sasanian coins}

Parthians (247 BC-224 AD) issued bimetallic silver and copper coins (Figure 1). It seems that gold coins were not regularly issued. In the cities authorized administrators issued bronze coins every year, but silver coins remained the main currency for commercial purposes. Parthians minted drachms for use in their homeland. The weight of their coins equaled Greek attic standard 4 gram (Sellwood 1979) while in Mesopotamia they issued tetradrachms (16 grammes). They kept this standard until the end of their kingdom. On each coin the Kings head is on the obverse and an archer seated on a throne is on the reverse. All Parthian coins carried Greek legends on their reverse, and after Mithridates I, the Seleucid date in years and months appeared on the reverse along with the minting house mark.

Silver issues were the backbone of the monetary system, economy and history of the Sasanians (224-651 AD, 
Figure 2. Sassanian mint houses.

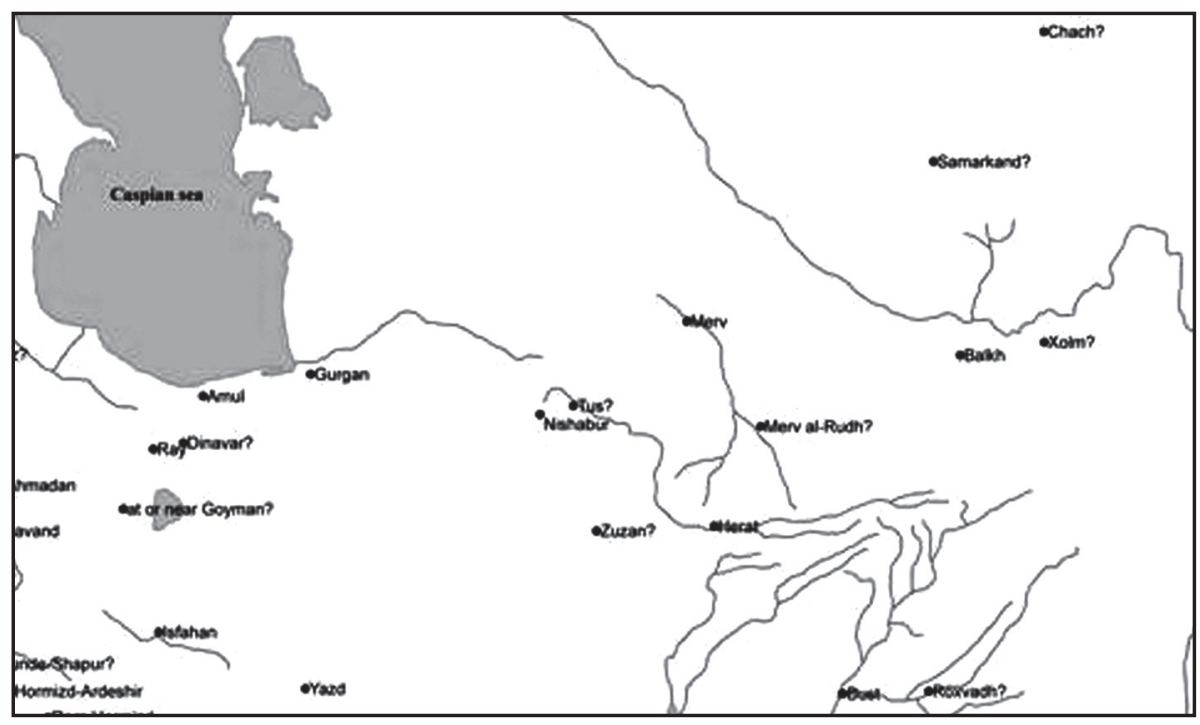

Figure 2). On each, the King's portrait was on the obverse (Goble 1971), and a Zoroastrian fire altar on their reverse. From Shapur II (241-272 AD) onwards two standing figures are seen on the reverse. There are a variety of gold and copper issues. The writing on all Sasanian coins was in Pahlavi script, with the year of coronation was indicated on them. Their bimetallic issues were gold and silver. Gold only issues were mainly ceremonial. Silver coin weights were not compatible with Attic and Roman standards, though double dinars may have been based on the Roman standard.

\section{Material and Methods}

\subsection{Preparation of samples}

Selected Parthian and Sasanian silver coins from the excavation layer were selected after cleaning from conservation division of the national museum. Coins were cleaned with $5 \%$ formic acid. They were cleaned again with alcohol in the XRF and PIXE lab to remove $\mathrm{NaCl}$, following which they were submitted for spectroscopy.

\subsection{Experimental setup}

A $2 \mathrm{MeV}$ proton beam with a current of 2-3 nA from an AEOI Van de Graff accelerator was used. Coins were kept in a multipurpose scatter chamber under high vacuum ( $10^{-5}$ Torr). X-ray emissions from the samples were detected by an ORTEC Si (Li) detector (FWHM $170 \mathrm{eV}$ at $5.9 \mathrm{keV}$ ). GUPIX software was used to analyze the captured spectra. Results are shown in Table 1 and include major elements ( $10 \%$ of metallic composition), minor elements $0.1-10 \%$ and trace elements (less than $0.1 \%$ ). The overall uncertainty for the PIXE method was 5\% for major elements, 5-10\% for minor elements and $15 \%$ for trace elements. Uncertainty was not only statistical, but also originated from the roughness of coin surface, chemical corrosion and/or wearing of the objects, which altered the accuracy of the results.

In another method for determining silver chemical composition, X-ray microanalysis using wavelength dispersive spectrometry (WDS) provides usable results, and allows for small sample sizes $\left(<1 \mathrm{~mm}^{3}\right)$. It is a relatively fast technique, and does not require the sample to be destroyed (Verita et al. 1994). However, since WDXRF results can be improved by

Figure 3. Percentage of Gold in Parthian silver coins, using PIXE.

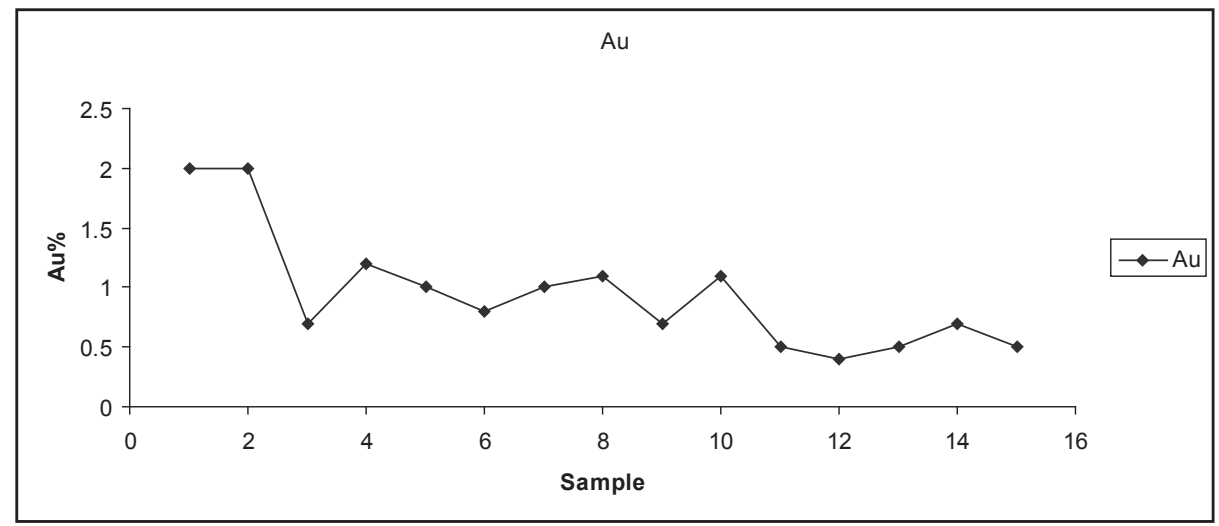


Table 1. Percentage of chemical elements in Parthian using PIXE. Remarks: coins number 3 seems to be billon (coins containing 50 percent silver) or copper and was removed from table.

\begin{tabular}{|c|c|c|c|c|c|c|c|c|c|c|c|c|c|}
\hline Sample & N. Muse & Cl & $\mathrm{Ca}$ & $\mathbf{F e}$ & $\mathrm{Cu}$ & Zn & Ag & & & $\mathbf{T i}$ & $\mathbf{S}$ & Name King & Weight \\
\hline 1 & 147 & 1.9 & 3.7 & 1.3 & 23.9 & 2.9 & 61.6 & & & 0 & 0 & Orodes II & 4.01 \\
\hline 2 & 144 & 0.7 & 0 & 0.1 & 5 & 0.1 & 100 & & & 0 & 0 & Orodes II & 3.35 \\
\hline 3 & 144 & 0 & 1.3 & 0.3 & 75.4 & 0 & 21.3 & & & 0 & 0 & Orodes II & 3.55 \\
\hline 4 & 1289 & 0 & 0.9 & 0 & 10.1 & 0 & 86.8 & & & 0 & 0 & Orodes II & 3.93 \\
\hline 5 & 1289 & 0 & 0 & 0 & 10 & 0 & 88 & & & 0 & 0 & Orodes II & 3.99 \\
\hline 6 & 1289 & 0 & 0 & 0 & 8.2 & 0 & 90.2 & & & 0 & 0 & Orodes II & 4.09 \\
\hline 7 & 1289 & 0 & 0 & 0 & 6.8 & 0 & 90.9 & & & 0 & 0 & Orodes II & 4.00 \\
\hline 8 & 1289 & 0 & 0 & 0 & 16.5 & 0 & 81.3 & & & 0 & 0 & Orodes II & 3.91 \\
\hline 9 & 1289 & 0 & 0 & 0 & 9.1 & 0 & 89.5 & & & 0 & 0 & Orodes II & 4.03 \\
\hline 10 & 1289 & 0 & 0 & 0 & 9.6 & 0 & 87.7 & & & 0 & 0 & Orodes II & 4.5 \\
\hline 11 & $\mathrm{~K}: 5$ & 3.9 & 2.5 & 0.7 & 16.3 & 0.1 & 63.1 & & & 0 & 1.4 & Phraates IV & 3.61 \\
\hline 12 & $\mathrm{~K}: 5$ & 1.3 & 1.1 & 0.5 & 21.1 & 0 & 66.1 & & & 0 & 0.5 & Phraates IV & 3.92 \\
\hline 13 & $\mathrm{~K}: 5$ & 3.6 & 1.3 & 0.1 & 9.1 & 0 & 83.1 & & & 0 & 0.5 & Phraates IV & 3.94 \\
\hline 14 & $\mathrm{~K}: 10$ & 4.3 & 2.7 & 0.3 & 4.9 & 0 & 73 & & & 0 & 7.9 & Phraaates IV & 3.62 \\
\hline 15 & $\mathrm{~K}: 3$ & 2.9 & 1.3 & 0.1 & 12 & 0 & 81.7 & & & 0 & 0 & Phraates IV & 3.69 \\
\hline SUM & & 18.6 & 14.8 & 3.4 & 238 & 3.1 & 1164 & 14.2 & 14.2 & $\mathbf{0}$ & 10 & & \\
\hline Aversilvere & & 1.24 & 0.987 & 0.227 & 15.867 & 0.207 & 77.62 & 0.95 & 0.95 & $\mathbf{0}$ & 0.7 & & \\
\hline STDEV & & 1.643 & 1.187 & 0.365 & 17.381 & 0.746 & 19.13 & 0.5 & 0.58 & $\mathbf{0}$ & 2 & & \\
\hline SE & & 0.424 & 0.306 & 0.094 & 4.4878 & 0.193 & 4.94 & 0.13 & 0.15 & $\mathbf{0}$ & 0.5 & & \\
\hline
\end{tabular}
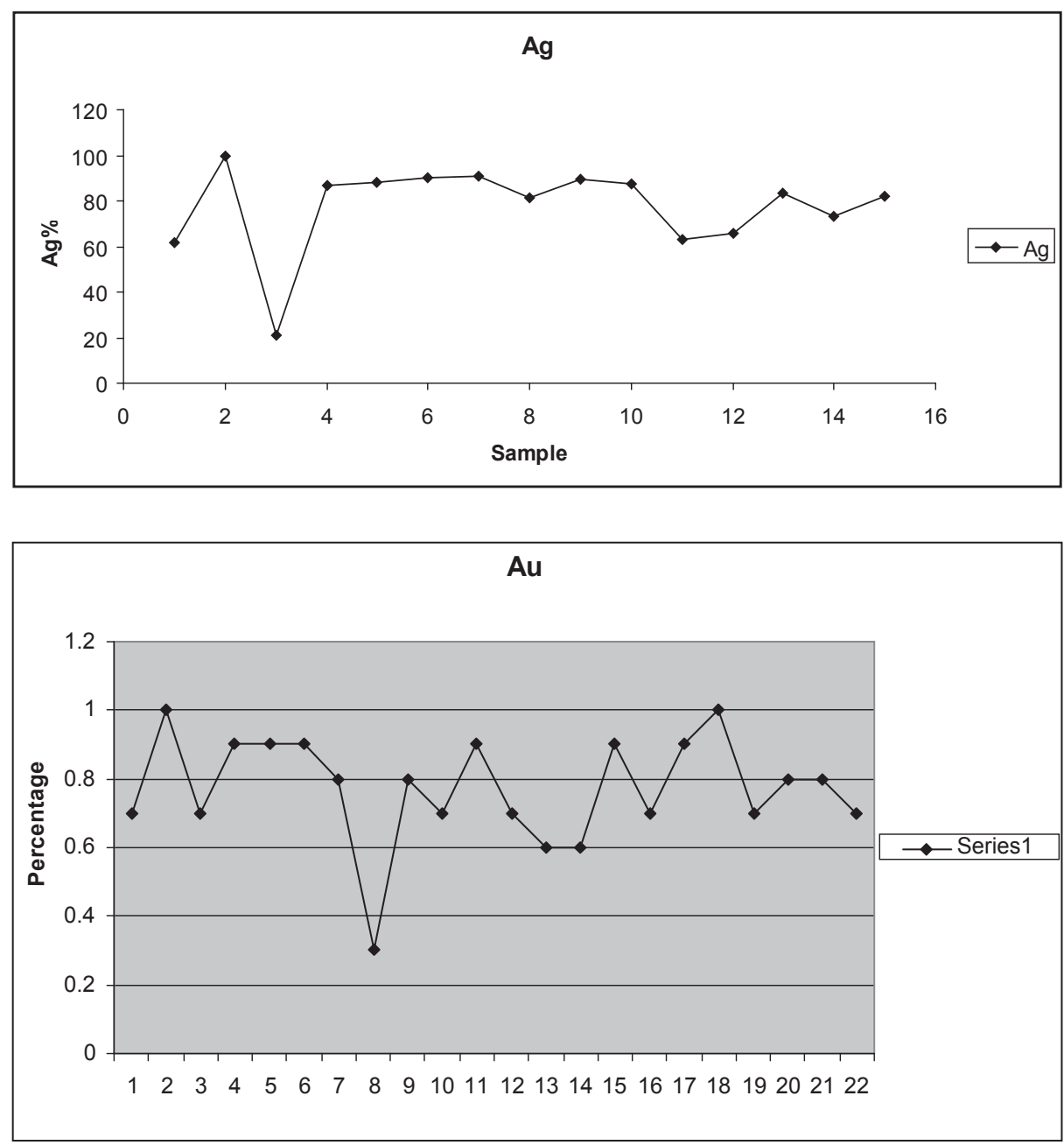

Figure 4. Percentage of silver present in Parthian silver coins.

Figure 5. Percentage of Gold in Sassanian silver coins using XRF. 
Table 2. XRF results for Sassanian silver coins, in percent

\begin{tabular}{ccccccc}
\hline Diameter & weight & Unit weight & Mint house & Regal year & King name & Coin No. \\
\hline 2.8 & 4.14 & Drachma & Istakhr & - & Piruz & 1 \\
2.8 & 3.77 & Drachma & Ardeshirkhoreh & - & Piruz & 2 \\
2.9 & 4.11 & Drachma & Ardeshirkhoreh & - & Belash & 3 \\
2.7 & 3.96 & Drachma & Istakhr & - & Kavad & 4 \\
2.7 & 3.56 & Drachma & Istakhr & 25 & Kavad & 5 \\
2.8 & 3.57 & Drachma & Ardeshirkhoreh & 30 & Kavad & 6 \\
2.9 & 3.36 & idgum & Darabgird & 30 & Kavad & 7 \\
2.8 & 4.00 & Drachma & Istakhr & 30 & Kavad & 8 \\
2.6 & 4.14 & Drachma & Darabgird & 34 & Kavad & 9 \\
2.9 & 3.99 & Drachma & Darabgird & 37 & Kavad & 10 \\
3.2 & 3.99 & Drachma & Ardeshirkhoreh & 40 & Kavad & 11 \\
3.1 & 4.03 & Drachma & Ramhormuz & 30 & Xusro I & 12 \\
2.9 & 3.40 & Drachma & Istakhr & 41 & Xusro I & 13 \\
3.0 & 3.54 & Drachma & Bishapur & 43 & Xusro I & 14 \\
3.15 & 4.08 & Drachma & Bishapur & 9 & Hormuz IV & 15 \\
3.1 & 4.11 & Drachma & Istakhr & 15 & Xusro II & 16 \\
3.2 & 3.93 & Drachma & Istakhr & 23 & Xusro II & 17 \\
3.2 & 3.98 & Drachma & Ecbatana & 25 & Xusro II & 18 \\
3.2 & 4.14 & Drachma & Ardeshirkhore & 35 & Xusro II & 19 \\
3.4 & 4.11 & Drachma & Sistan & 36 & Xusro II & 20 \\
3.1 & 3.98 & Drachma & Sistan & 38 & Xusro II & 21 \\
3.1 & 4.15 & Drachma & Ecbatana & 2 & Kavad II & 22 \\
3.2 & 4.11 & Drachma & Iran & 2 & Kavad II & 23 \\
3.1 & 4.17 & Drachma & Istakhr & 2 & Ardeshir III & 24 \\
3.2 & 4.10 & Drachma & Bishapur & 2 & Ardeshir III & 25 \\
3.2 & 4.01 & Drachma & Sistan & 19 & Yazdgird III & 26 \\
\hline
\end{tabular}

\begin{tabular}{ccccccc}
\hline $\mathbf{C u}$ & $\mathbf{C a}$ & $\mathbf{F e}$ & $\mathbf{A u}$ & $\mathbf{P b}$ & $\mathbf{A g}$ & Coin No. \\
\hline 2.583 & 0.484 & 0 & 0.69 & 0 & 93.833 & 1 \\
1.289 & 0.681 & 2.13 & 0.952 & 0 & 81.371 & 2 \\
1.326 & 0.947 & 7.188 & 0.714 & 0 & 82.531 & 3 \\
1.045 & 1.378 & 0.3 & 0.941 & 0 & 93.787 & 4 \\
6.455 & 1.904 & 3.524 & 0 & 0 & 72.083 & 5 \\
3.375 & 0.899 & 0.286 & 0.874 & 0 & 90.527 & 6 \\
85.504 & 9.724 & 0.182 & 0 & 0.457 & 0 & 7 \\
2.448 & 1.47 & 0 & 0.883 & 0 & 92.084 & 8 \\
1.28 & 5.244 & 0.278 & 0.756 & 0 & 83.176 & 9 \\
4.337 & 1.778 & 0.921 & 0.275 & 0 & 78.865 & 10 \\
3.088 & 12.829 & 0.425 & 0.845 & 0 & 77.633 & 11 \\
3.174 & 6.187 & 0.591 & 0.689 & 0 & 80.923 & 12 \\
2.652 & 0 & 0 & 0.872 & 0 & 95.79 & 13 \\
9.578 & 4.321 & 0 & 0.686 & 0 & 77.688 & 14 \\
0.579 & 11.111 & 1.136 & 0.595 & 0.57 & 73.093 & 15 \\
5.324 & 2.732 & 0 & 0.643 & 0.709 & 77.493 & 16 \\
1.347 & 0.77 & 0.223 & 0 & 0.88 & 89.285 & 17 \\
0.821 & 1.721 & 0 & 0.924 & 0 & 83.113 & 18 \\
1.98 & 0 & 1.112 & 0.737 & 0 & 83.948 & 19 \\
1.793 & 2.371 & 0 & 0.879 & 0 & 86.283 & 20 \\
3.135 & 2.087 & 0 & 1.033 & 0 & 89.071 & 21 \\
3.992 & 0 & 0 & 0 & 0 & 92.892 & 22 \\
2.134 & 0 & 0 & 0.697 & 0 & 95.319 & 23 \\
1.305 & 2.438 & 0.249 & 0.758 & 0 & 90.343 & 24 \\
1.855 & 0.995 & 0 & 0.761 & 0 & 87.682 & 25 \\
5.801 & 0.527 & 0.326 & 0.748 & 0.782 & 83.154 & 26 \\
\hline & & & & & &
\end{tabular}




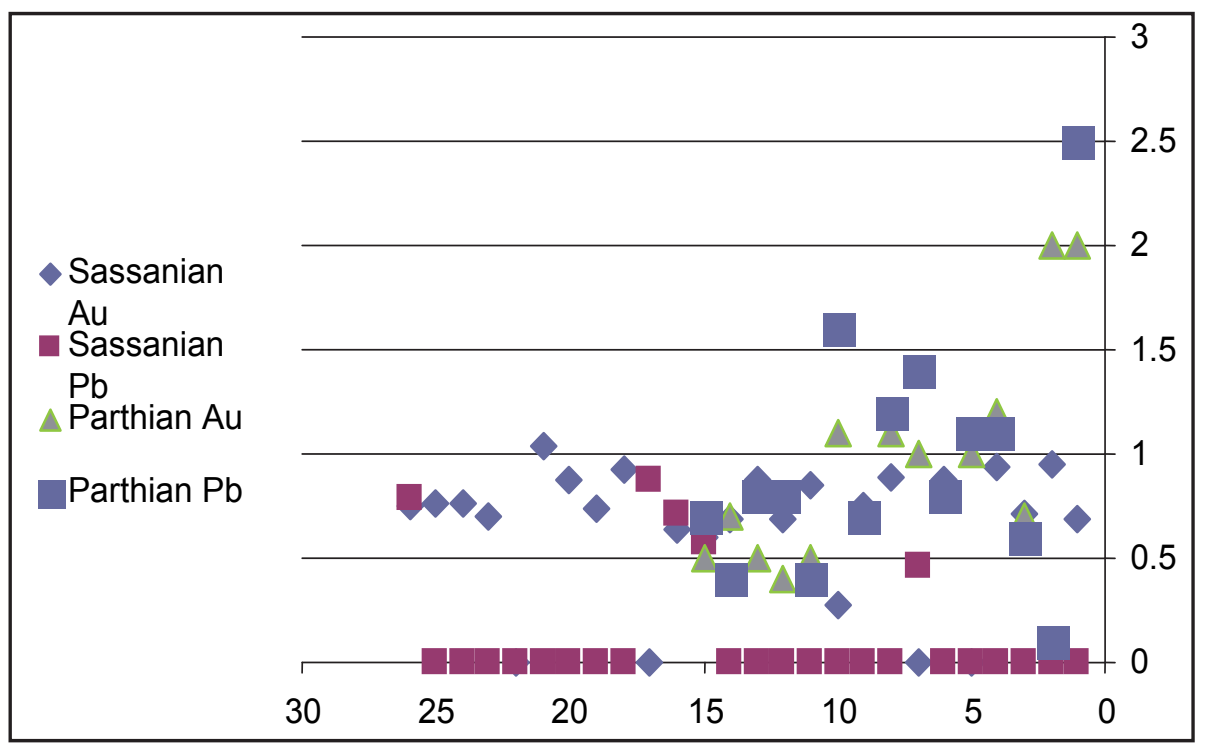

Figure 6. Results in percents, XRF could not detect the $\mathrm{Pb}$ concentration of some coins.

processing powdered samples, several Parthian and Sasanian coins were pulverized for spectroscopy using a Philips PW2404 XRF instrument calibrated to CPM standards for the most accurate results, and limitation of detection was $0.01 \%$.

\section{Results and Discussion}

Spectroscopy of Parthian and Sasanian coins (Table 1 and 2) shows that the silver was of a higher quality than contemporary neighbouring civilizations. After analyzing Roman and Sasanian silver plates by Hughes (Hughes, Hall 1979, 365-73) also concluded that there is less lead in Sasanian silver plates compared to Roman coins. This is thought to indicate a greater effort on the part of Sasanian metal workers as silver was the primary exchange metal, while the Romans preferred gold, In any case silver had a critical economic role in the Sasanian period.

Lead content is a determinant of technology and quality (Figure 6) in the Parthian and Sasanian period, This chart shows the extraction of silver in Sasanian period were very better in compare with Sasanian period. Figure 4 shows variation of silver in the Parthian period as it is not observable in the Sasanian silver coins. Gold helps identify the sources of mines of silver in different silver sources from different lead-zinc mines during the Parthian period. Coins no. 1 and 2 on Figure 3 and coin number 8 on Figure 5 belonging to the Sasanian period has similar features as those of the Parthian period, that is, new sources for silver metals was used for extraction.

\section{Conclusion}

It seems that Sasanian concentrated their efforts on refining silver, possible driven by the importance of silver to the royal household and needs. The higher purity of Sasanian silver coins, compared to Roman coins, indicates that Sasanian were better than Romans in refining silver. It also indicates that Sasanian metal workers were more skilled compared to their Roman contemporaries. The concentration of $\mathrm{Au} / \mathrm{Ag}$ in the silver coins used to identify the sources of silver, are almost same in both the Parthian and Sasanian periods, and it is possible that several same mines were in use.

The concentration of gold in silver coins during the Parthian period shows that the sources of silver coins 1 and 2 were different. The silver coin no. 8 of Sasanian period is similar to coins 1 and 2 denoting that its source is different.

It may be inferred that during political and economic crises Parthian reduced the percentage of silver in their silver Drachma coins, but Sasanian kept silver in their silver coins during hard times and in order to cope with political and economic crises they increased taxes instead of decreasing percentage of silver in their issues.

\section{References}

BACHARACH, J. L, GORDUS, A. A. 1972: The purity of Sasanian silver coins: An Introduction, Journal of the American Oriental Society 92-2, 280-83.

BANKS, M., HALL, E. T. 1963: X-Ray Fluorescent Analysis in archaeology: The milliprobe, Archaeometry 6-1, 31-36.

CESAREO, R., FRAZZOLI, F. V., MANCINI, C., SCIUTI, S., MARABELli, M., P. MORA, P., ROTONDI, P., URBANI, G. 1972: Non-Destructive Analysis of chemical elements in painting and enamels, Archaeometry 14-1, 65-78.

CONDAMIN, J., PICON, M. 1964: The influence of corrosion and Diffusion of the percentage of silver in Roman Denarii, Archaeometry 7-1, 98-105.

GOBL, R. 1971: Sasanian Numismatics. Klinkhardt und Biermann, Braunschweig.

GONDONNEAU, A., GUERRA, M. F. .2002: The circulation of precious metals in the Arab Empire: The case of the near and the Middle East, Archaeometry 44-4, 573-599. 
GORDUS, A. A. 1972: Neutron Activation Analysis of coins and coinsstreaks. In: HALL, E. T., METCALF, D. M. (Eds.): Methods of chemical and metallurgical of Ancient coinage, Royal Numismatic Society spec, publ. 8, 127-148.

GORDUS, A. A. 1995: Neutron Activation Analysis of Microgram Samples of Sasanian Coins and Metallic Art, Material Issues in Art and Archaeology IV. In: Materials Research Society Symposium Proceedings, Vol. 352 Pittsburgh, U.S.A, 613-20.

GUERRA, M. F. 1998: Analysis of Archaeological Metals. The place of $\mathrm{XRF}$ and PIXE in the determination of Technology and Provenance. $X$-Ray Spectrometery 27-2, 73-80.

HALL, E. T., SCHWEIZER, F., TOLLER, P. A. 1973: X-Ray Fluorescence Analysis of Museum object: A new instrument, Archaeometry 15-1, 53-78.

HUGHES, M. .J., HALL, J. A. 1979: X-ray Fluorescence Analysis of late Roman and Sasanian Silver plate, Journal of Archaeological Science 6-2.

HAJIVALIEI, GARG, M. L., HANDA, D. K., GOVIL, K. L., KAKAVAND, T., VIJAYAN, V., SING, K. L., GOVIL I. M. 1999: PIXE analysis of ancient Indian coins, Nuclear Instruments and methods in Physics Research B, 150,1-4, 645-650.

HAJIVALIEI, MOHAMMADIFAR, M. Y., GHIYASI, K., JALEH, B., LAMEHI-RACHTI, M. P., OLIAIY, P. 2008: Application of PIXE to study ancient Iranian silver coins, Instrument and methods in Physics, Research: Beam interaction with material and Atoms 266, 1578-1582.

JESUS, S. D. 1978: Metal resources in Ancient Antolia, Anatolian studies 28, 97-102.

KANTARELOU, V. et al. in press: XRF analytical criteria to assess the fineness of ancient silver coins: Application on Ptolemaic coinage, Spectrochmica Acta acta part B: Atomic spectroscopy 10 .

MEYERS, P. 1972: Activation analysis methods applied to coins: a review. In: Hall, E. T., Metcalf, D. M. (Eds.): Methods of chemical and metallurgical investigation of ancient coinage. Royal Numismatic Society, London, Special Publication 8, 183-193.
MEYERS, P. 2003: Production of silver in antiquity: ore types identification based upon elemental composition of ancient silver artifacts. In Zelset, L. V., (Ed.): Patterns and process. Maryland, USA, 271-288.

MOMENZADEH, M. 1996: Survey of the mines and mines working in Ancient Iran, Cheshmeh, spring, 21-59.

NEZAFATI, N., PERNICKA, E., MALEK SHAMIRZADI, S. 2008: Evidence on the ancient mining and metallurgy at Tappeh Sialk (Central Iran). In: International conference AMITEM, Turkey, 329-349.

RAUTRAY, T. R., SAUBHAGYALAXMI, D., MANAS, R. D., SATTYA, R. D., CHATTOPADHYAY, P. K. 2011: Analysis of ancient silver punch-marked coins by external PIXE, Applied Radiation and Isotope 69-10, 1385-1389.

SELLWOOD, D. J. 1979: An Introduction to the Parthian coins. London. SMITH, S. T. 2001: Numismata Orientalia Regni Bohemiae: Corpus Sasanicus, Oriental Numismatic Society News Letter, 8-9.

SMIT, Z. 2005: Recent developments of material analysis with PIXE, Nuclear Instrument and Methods in Physics, Research B 240-1-2, 258-264.

VIJAYAN, V., RAUTRAY, T. R., BASA, D. K. 2004: EDXRF study of Indian Punch-marked silver coins, Nuclear Instruments and methods in Physics Research B 225-3, 353-356.

WEBER, G, GUILlAUME, J., STRIVAY, D., GARNIR, H. P., MARCHAL, A., L MARTINOT, L. 2000: Is the external beam PIXE method suitable for determining ancient silver artifact fineness? Nuclear Instruments and methods in Physics Research B 161-163, 724-729.

YAKAR, J. 1976: Hittite involvement in western Anatolia, AS XXVI, $118-128$

YENER, K. A. 1983: The production, exchange and utilization of silver and lead metal in Ancient Anatolia, Anatolica X, 1-15.

YENER, K. A. 1986: The archaeometry of silver in Anatolia: The Bolkardage Mining district, American Journal of Archaeology 90, 469-472. 
